\title{
Ecological and Economical Substatiation of Production of Hydrogen
}

\author{
Nataliia Kovalenko \\ Faculty of Agrarian management \\ National University of Life and \\ Environmental Sciences of Ukraine \\ Kyiv, Ukraine \\ n.kovalenko@it.nubip.edu.ua \\ Szymon Glowacki \\ Institute of Mechanical Engineering \\ Warsaw University of Life Sciences - \\ SGGW \\ Warsaw, Poland \\ glowackisz@gmail.com
}

\author{
Taras Hutsol \\ Institute of Energy, \\ State Agrarian and Engineering \\ University in Podilia, \\ Kamianets-Podilskyi,Ukraine \\ pro-gp@pdatu.edu.ua \\ Dmytro Sorokin \\ Department of Electrical \\ Engineering, Electromechanics and \\ Electrotechnology \\ National University of Life and \\ Environmental Science of Ukraine \\ Kyiv, Ukraine \\ sdima.asp@gmail.com
}

\author{
Oleksander Labenko \\ Economical Faculty \\ National University of Life and \\ Environmental Sciences of Ukraine \\ Kyiv, Ukraine \\ labenko@nubip.edu.ua
}

\begin{abstract}
Hydrogen production from biomass may become one of the leading areas of bioenergy in Ukraine soon. Currently, the main direction of biomass energy production in Ukraine is the production of thermal energy for distributed heat supply of enterprises and private households by burning biomass of wood and agricultural origin. Nowadays in Ukraine, there is a technology for the production of biohydrogen. We calculated the environmental and economic effects of hydrogen production as a source of energy. We have come up with the following conclusion that if there is a demand for the final product, hydrogen production will be attractive from economic standpoint and will not require a green tariff or other support from the government. The market price of biohydrogen will be \$ 4-5 per $\mathrm{kg}$ and will be comparable to that which the European Union aims to achieve. We assume that hydrogen may be a cleaner source of energy for end users, especially in the transport sector in the future.

One of the main issues of Ukraine's possible participation in Europe's hydrogen energy program as a supplier and producer of renewable hydrogen is the possibility of its technically safe and cost-effective transportation to EU countries.

As the main hypothesis considered transportation of hydrogen using the gas transmission system of Ukraine as part of a mixture with natural gas. Calculations show that, of course, obtaining energy from hydrogen, even in mass production, will be more expensive than alternative traditional and non-traditional methods. The development
\end{abstract}

of this technology, in any case, is promising in terms of the development of energy independence and environmental development of states. The effect of scale in mass production of hydrogen energy should also work, which will significantly reduce the cost of this technology.

Keywords - hydrogen, ecology, bioenergy, biohydrogen, natural gas.

\section{INTRODUCTION}

The Integration of Ukraine's economy into the European and world economy and the high level of its dependence on the external supply of traditional energy sources (oil and gas) due to the deficit of its own, necessitates the introduction of strategic directions of the domestic bioenergy market. Adoption of legislation aimed at creating favorable conditions for increasing the use of renewable energy sources while identifying strategic priorities in the development program of domestic bioenergy, will achieve the goals of sustainable development of society through the system "maneconomy-nature". Ultimately, such an approach will not only allow not to violate the principles of ensuring the energy balance of Ukraine, but also help to preserve the environment and solve social problems.

The development of hydrogen technology is gaining popularity around the world. Currently, the main direction 
of biomass energy production in Ukraine is the production of thermal energy for district heating of enterprises and private households by burning biomass of wood and agricultural origin. The hydrogen economy remains a matter of the future, but hydrogen technologies for energy, such as hydrogen storage of renewable energy, hydrogen storage for autonomous and distributed generation, refueling for ever-increasing quantitative and qualitative hydrogen transport, are actively introduced into the economies of developed countries [1,2] .

Hydrogen energy includes a set of technologies for the production, transportation, accumulation and use of a universal secondary energy source - hydrogen. In the concept of hydrogen energy, hydrogen complements the most important secondary energy source - electricity, energy use of hydrogen is determined by the possibility of environmentally friendly electricity generation and longterm storage without losses, including large-scale. The problem of using hydrogen as a promising environmentally friendly and universal energy source and energy accumulator in various sectors of the economy was formulated in the early 70s of last century after the first oil fuel crisis. It became clear that it is necessary to develop new environmentally friendly energy technologies based on the use of renewable energy sources, nuclear energy, coal and universal environmentally friendly energy sources that can replace non-renewable energy resources as they become depleted and more expensive $[3,4]$.

From an ecological point of view, the concept of "green hydrogen" is not always environmentally friendly. Technological processes associated with the manufacture of equipment for hydrogen production are completely non-ecological. This is still an ecologically dirty chain of processes, starting from the stage of extraction of rare earth metals. Thus, the "dirty" part of the technological processes that ensure the production of "clean" electricity from renewable energy sources, simply taken (with all their negative environmental and climatic effects) far beyond the EU - mainly in Asian countries. But the global climate problem is not regional but global.

According to the new "Green Course" of the European Commission (Green New Deal), the main bet is made on the use of renewable energy sources and decarbonized gases, primarily hydrogen. In this case, hydrogen is considered both as an energy source and as a means of accumulating excess electricity from renewable energy sources during periods of active sun and wind, when their production exceeds consumer demand and can be preserved.

According to the nomenclature used by the research firm Wood Mackenzie, most of the gas, which is already widely used as an industrial chemical, or brown, if it is produced by gasification of coal or lignite; or gray, if it is carried out by steam conversion of methane, which usually uses natural gas as a raw material. None of these processes are completely safe in terms of carbon emissions. Presumably a cleaner option is known as blue hydrogen, where the gas is produced by steam conversion of methane, and emissions are reduced by capturing and storing carbon. This process can halve carbon emissions, but it is still a long way from carbon-free production. On the other hand, green hydrogen can almost completely eliminate harmful emissions by using renewable energy fast-growing and often generated in less favorable periods of time - to power water electrolysis [5].

\section{MATERIALS AND METHODS}

For our analytical study on the prospects for the development of biohydrogen projects in Ukraine, we used materials from existing bioenergy foundations in Ukraine and Europe. Among the domestic organizations - the Bioenergy Association of Ukraine (UAIBO,) which includes the well-known Scientific and Technical Center "Biomass", Accord Ltd and the public association "Agency for Renewable Energy".

The methodological support of the study was based on a systematic approach, which allowed to reflect the state of research on hydrogen technology, to justify the need to develop energy from hydrogen, taking into account the environmental approach, to calculate and analyze the economic components of hydrogen development. They also used a graphical and analytical method, which allowed to summarize and visualize the studied processes.

\section{RESULTS AND DISCUSSION}

One of the main issues of Ukraine's possible participation in Europe's hydrogen energy as a supplier and producer of renewable hydrogen is the possibility of cost-effective production and technically safe transportation to EU countries. At the moment, it makes no sense to approach hydrogen production only from an economic point of view. Traditional types of energy production are certainly much cheaper and proven. But traditional fuels are non-renewable and often environmentally polluting, which is why humanity has turned to renewable sources.

\section{Environmental component of hydrogen production}

Negative environmental consequences of the use of petroleum fuels are already visible in large industrial centers, primarily due to transport [6]. Thus, in a city with a population of about 1 million inhabitants, the share of vehicles accounts for almost $70 \%$ of the total amount (several hundred tons per day) of environmentally harmful, including toxic emissions. Common forecasts say that by 2030 the number of cars on the planet will double to 1.6 billion.

Whether hydrogen production is environmentally friendly depends on the presence or absence of $\mathrm{CO} 2$ emissions at the end of the process. Today, the vast majority of hydrogen in the world is from the gray category. It is extracted from fossil fuels such as natural gas or coal. And such hydrogen is harmful to the environment, because the process of its production causes huge emissions of CO2. Natural gas is a fossil fuel whose entire life cycle is accompanied by greenhouse gas emissions, and renewable energy sources produced from renewable raw materials are biomass. By replacing 
natural gas with biohydrogen, we reduce greenhouse gas emissions and thus prevent environmental catastrophe.

Therefore, the transition to the use of hydrogen as a motor fuel in transport is a promising task. The undeniable advantages of the new fuel, firstly, are that with any release of energy using hydrogen (fuel cell, conventional heating, internal combustion engine) we have a favorable energy / mass ratio. That is, hydrogen is an extremely energy-intensive fuel. Thus, when it is burned per unit mass, almost 3.5 times more heat is released than when burning hydrocarbon oils or coal. It is especially important that in the case of hydrogen use there will be almost no emissions of harmful substances, especially carbon dioxide. After all, when hydrogen is burned, only water is formed.

Hydrogen fuel also has its drawbacks: the probability of explosion of the system when the normalized pressure in it is exceeded; it is not always possible to find hydrogen cylinders within walking distance (it is not natural propane gas). The technology has not been fully tested, it takes time to refine and experiment.

\section{Economic component of hydrogen production}

During the swift development of solar and wind energy among experts and politicians is growing awareness of the need to use a new gaseous carrier of renewable energy, which would allow not only to compensate for seasonal unevenness and poor predictability of solar and wind generation, but also to completely decarbonize other sectors of the economy heat, transport, metallurgy, chemical industry and others.

"Green" hydrogen produced without any use of fossil fuels was almost unanimously recognized as such an energy carrier.

Green hydrogen production requires large-scale production of a wide range of new related equipment and infrastructure elements. Electrolyzers and fuel cells, hydrogen engines and specialized vehicles, gas stations and means of transportation and storage.

A direct competitor to hydrogen, natural gas today costs around \$220 per 1,000 cubic meters, containing $40,000 \mathrm{MJ}$ of energy. The equivalent volume of hydrogen is $\sim 3700 \mathrm{~m} 3$. That is, to be competitive in the domestic market with natural gas, $1000 \mathrm{~m} 3$ of hydrogen must cost $\sim$ \$ 60, which corresponds to \$ 0.67 / kg. To begin with, biohydrogen needs to be produced by investing considerable funds in the construction of biohydrogen complexes. At the same time, as mentioned earlier, the approximate cost of biohydrogen production will be, on average (according to Akkord Ltd), \$ 600 per 1000 m3, which is 10 times more expensive than gas and will be $\$$ $6.7 / \mathrm{kg}$.

Let's see what is happening with the price of natural gas in the markets in recent years and what are the forecasts for the future.

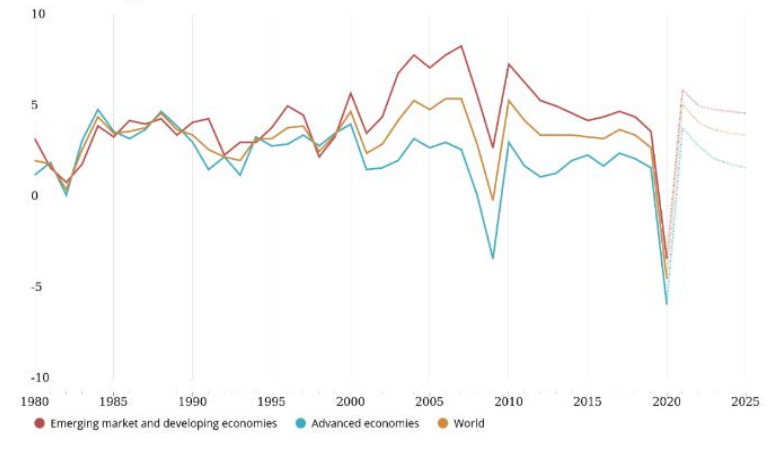

Fig. 1. Real GDP growth (annual percent change) [7].

According to experts in the longer term, the EU GDP growth is projected to slow down to $1.7 \%$ per year between 2020 and 2030.

Thus, to produce hydrogen to replace natural gas - it is possible, but economically - it's impractical now and the situation will change little in future, if we consider only the economic approach.

In Europe and the United States, it's predicted that the cost of hydrogen is projected to decline when considering several technology development scenarios and increased production. According to the forecast of the first scenario, it is assumed that the cells are connected to the grid and can produce hydrogen with a power factor of $100 \%$. The minimum price in Europe is expected to fall from \$ 4.83 / $\mathrm{kg}$ now to $\$ 3.21$ / kg by 2050. In the US, the lowest price of hydrogen production in 2050 is expected to be almost a dollar higher - \$4.15/ kg (at \$6.06/ kg at present). According to the forecast of the second scenario, it is assumed that the cells are not connected to the grid, but instead are connected directly to power plants that generate electricity from renewable energy sources. In this scenario, the average price of hydrogen production in the United States will fall from the current $\$ 10.61 / \mathrm{kg}$ to \$ 5.97 / kg, and the minimum price will fall from \$ 4.56 / $\mathrm{kg}$ to $\$ 2.44 / \mathrm{kg}$. It is expected that in Europe the minimum price will be even lower - \$ 2.23 / kg (at \$ 4.06 $/ \mathrm{kg}$ at present), and the average price will decrease from $\$ 19.23$ / kg - to \$ 10.02 / kg in 2050 [8].

In terms of electricity substitution, hydrogen may also be attractive in Ukraine to participate in European hydrogen technology projects.

$1 \mathrm{~m}^{3}$ of hydrogen weighs $89.8 \mathrm{~g}$ (44.9 mol), so to obtain $1 \mathrm{~m}^{3}$ of hydrogen will be used $12832.4 \mathrm{~kJ}$ of energy. $1 \mathrm{kWh}=3600 \mathrm{~kJ}$, so we get $3.56 \mathrm{kWh}$ of electricity. The feasibility of switching to hydrogen fuel can be assessed by comparing the existing tariff per 1 $\mathrm{kWh}$ of electricity and, for example, the cost of $1 \mathrm{~m}^{3}$ of gas or the cost of another energy source.

As we received earlier, the cost of hydrogen is currently $\$ 6.7 / \mathrm{kg}$, but experts aim to reduce it to the European $4.83 / \mathrm{kg}$ (\$ 430 per $1000 \mathrm{m3}$ ), \$ 0.43 per 1 $\mathrm{m} 3$ (which will be $3.56 \mathrm{kWh}$ of electricity). Therefore, the cost of $1 \mathrm{kWh}$ of electricity will cost $\$ 0.15$ or 0.13 euros. 
Compared to the current tariff in Ukraine - 0.05 euros, the calculations are not profitable. But 0.13 euros is the cost of hydrogen that Europe is counting on in its hydrogen strategy and with which it can start synergies.

Regarding the attractiveness of using hydrogen for transport

$1 \mathrm{~kg}$ of natural gas $(55.6 \mathrm{~mJ})$ is $1.39 \mathrm{~m} 3$, currently it costs \$ 0.37 / kg in Ukraine. Per $100 \mathrm{~km}$ requires 10-12 $\mathrm{kg}$ of gas, which will average $\$ 4.07$.

A hydrogen supply of 5-7 kg is enough for a mileage of about $500 \mathrm{~km}$ - on average, the developers promise to achieve hydrogen consumption, which will be about 1 liter per $100 \mathrm{~km}$, but in reality the flow is $1.1-1.3 \mathrm{~kg}$ per $100 \mathrm{~km}$ [9]. We have such a high efficiency of hydrogen use due to the efficiency of internal combustion engines: the efficiency of gas combustion - 10-42\%, the efficiency of hydrogen combustion - 75-85\%.

$1 \mathrm{~kg}$ of hydrogen - 11.1 cubic meters (142.43 mJ), take the minimum projected cost of $\$ 2.23-4.3 / \mathrm{kg}$ or it will be $\$ 2.7-5.5$ per $100 \mathrm{~km}$. Even in a more expensive scenario, the cost of $100 \mathrm{~km}$ is economically comparable and, of course, environmentally efficient.

What then hinders the development of this technology. Fuel cells and volumetric hydrogen cylinders are the "heart" of the entire hydrogen car system. With cylinders, everything is simple and clear: multilayer composite materials; today they already have a relatively low cost; good resistance to destruction; they take the place of the fuel tank and the trunk pallet. But with fuel cells, everything is much more complicated: they are expensive to produce (used platinum coating) and can be easily destroyed. The cost of such an engine will be many times more expensive than those we have today and there aren't many consumers who are willing to buy a car more expensive just to save the environment. But we believe that this technology is very promising for large industries in transport, such as aircraft, large water transport, trains.

\section{CONCLUSION}

After conducting preliminary calculations, we came to the following conclusions. Projects to replace natural gas with hydrogen, today, from an economic point of view are not profitable. The process of adding hydrogen to the gas system of Ukraine requires additional research, in terms of a safe maximum ratio of gas and hydrogen. Some scientists talk about the limit range of $5-10 \%$, others push it to $20 \%$. All in one - the inevitability of hydrogen corrosion and increased brittleness of the metal when using traditional carbon steels, due to the penetration of very small hydrogen molecules into their crystal lattice. Each individual situation requires painstaking research and largely depends on the condition and wear of the system. For this reason, in many countries around the world are building special separate water pipelines, which transport pure hydrogen, suitable for further use in fuel cells. According to average estimates, the cost is approximately $60-70 \%$ higher than the cost of construction of standard gas pipeline systems. The necessary infrastructure is also undergoing the necessary changes in this case.

Regarding the production of electricity from hydrogen, while achieving a reduction in the cost of hydrogen production to 4.83 , we will get a result that is currently attractive for Europe and will attract potential investors.

The most attractive are the calculations for the use of hydrogen in the transport system, which is perhaps the largest polluter of the ecosystem. An obstacle to development is the increase in the cost of cars if they switch to hydrogen technology, but this does not diminish the importance of technology for major transport.

\section{REFERENCES}

[1] Dudnikov, D., etal., Hydrogen energy techmologies.M.: OIVT RAN, 2017. Rel. 1. 190 c.

[2] Perederiy, N., Kuzmenko, S., Labenko, O., Energy-saving technologies in agriculture of Ukraine. Quantitative methods in economics.Volume XVII, No. 4, 2016, p. 89-100. [Online]. Available: https://www.ceeol.com/search/articledetail?id=473655. [Accessed Jan. 24, 2021].

[3] Kovalenko, V., Kovalenko, N., Labenko, O., Faichuk, O. and Faichuk, O. ,Bioenergy sustainable development: achieving the balance between social and economic aspects. E3S Web of Conferences 154, 2020, 07008. [Online]. Available: https://www.e3s-

conferences.org/articles/e3sconf/abs/2020/14/e3sconf_icores2020 07008/e3sconf_icores2020_07008.html. [Accessed Jan. 21, 2021].

[4] Malyshenko, S.P., Borzenko, V.I., Dunikov, D.O., Nazarova, O.V., Metal hydride technologies of hydrogen energy storage for independent power supply systems constructed on the basis of renewable sources of energy. Thermal Engineering, 2012, T. 59, № 6. p. 468-478.

[5] Energy club. [Online]. Available:https://iclub.energy. [Accessed Jan. 25, 2021].

[6] The Hydrogen Economy: Opportunities, Costs, Barriers, and R\&D Needs. National Research Council and National Academy of Engineering. 2004. [Online]. Available: https://www.nap.edu/read/10922/chapter/1\#ii. [Accessed Jan. 25, 2021].

[7] International Monetary Fund. [Online]. Available: https://www.imf.org/external/datamapper/NGDP_RPCH@WEO/ OEMDC/ADVEC/WEOWORLD. [Accessed Jan. 25, 2021].

[8] Tsina vodniu z VDE vyroblenoho $\mathrm{v}$ YeS ta SShA mozhe buty zmenshena maizhe vdvichi do 2050r. [The price of hydrogen from RES produced in the EU and the US could be reduced by almost half till 2050]. [Online]. Available:

[9] https://expro.com.ua/novini/cna-vodnyu-z-vde-viroblenogo-v-sta-ssha--buti-zmenshena-mayje-vdvch-do-2050r. [Accessed Jan. 26, 2021].

[10] Mohut li vodorodnye avtomobili sostavit konkurentsiiu elektromobiliam? [Can hydrogen cars compete with electric cars?].[Online]. Available: https://e-move.com.ua/mogut-livodorodnye-avtomobili-sostavit-konkurenciyu-elektromobilyam/. [Accessed Jan. 31, 2017].

[11] Tryhuba, A.; Hutsol, T.; Tryhuba, I.; Pokotylska, N.; Kovalenko, N.; Tabor, S.; Kwasniewski, D. Risk Assessment of Investmentsin Projects of Production of Raw Materials for Bioethanol. Processes 2021, 9,12, doi:10.3390/pr9010012.

[12] Tryhuba, A.; Bashynsky, O.; Hutsol, T.; Rozkosz, A.; Prokopova, O. Justification of Parameters of the Energy Supply System of Agricultural Enterprises with Using Wind Power Installations. In Proceedings of the 6th International Conference - Renewable 
Energy Sources (ICoRES2019), E3S WebConf, 2020, Volume154, 06001, doi:10.1051/e3sconf/202015406001.

[13] Huber, G.W.; Dumesic, J.A. Anoverviewofaqueousphasecatalyticprocessesforproductionofhydrogenandalkanesinabio refinery. Catal. Today 2006, 111,119132,doi:10.1016/j.cattod.2005.10.010.

[14] Zhou, C.; Xia, X.; Lin, C.; Tong, D.; Beltramini, J.Catalyticconversionoflignocellulosicbiomasstofinechemicalsand fuels.Chem. Soc. Rev. 2011, 40,55885617,doi:10.1039/C1CS15124J.

[15] Kayfeci, M.; Keçebaş, A.; Bayat, M. Hydrogenproduction. Solar Hydrog. Prod. Process. Syst. Technol. 2019,4583,doi:10.1016/B978-0-12-814853-2.00003-5.

[16] Nikolaidis, P.; Poullikkas, A. Acomparative overview of hydrogen production processes. Renew. Sustain. Energy Rev. 2017, 67,597-611, doi:10.1016/j.rser.2016.09.044.

[17] Ishaq, H.; Dincer, I. Comparative assessment of renewable energy-based hydrogen production methods. Renew. Sustain. Energy Rev. 2021, 135, 110192, doi:10.1016/j.rser.2020.110192.

[18] Golub, G.; Skydan, O.; Kukharets, V.; Yarosh, Y.; Kukharets, S. The estimation of energetically self-sufficient agroecosystem' smodel. J. Cent. Eur. Agric. 2020, 21, 168-175, doi:10.5513/JCEA01/21.1.2482.

[19] Meng Ni, M.;Leung, D.Y.; Leung, M.K.; Sumathy, K. An overview of hydrogen production from biomass. Fuel Process. Technol. 2006, 87, 461-472, doi:10.1016/j.fuproc.2005.11.003.

[20] Diachuk, O.; Chepeliev, M.; Podolets, R.; Trypolska, G.; oth.Transition of Ukraine to the Renewable Energyby 2050. In
Heinrich Boell Foundation Regional Office in Ukraine; Publishing house “ArtBook” Ltd.: Kyiv, Ukraine, 2017; Volume $88 . \quad$ Available online: https://ua.boell.org/sites/default/files/transition_of_ukraine_to_the _renewable_energy_by_2050_1.pdf (accessed on 1 November 2017).

[21] Tryhuba, A.; Hutsol, T.; Glowacki, S.; Tryhuba, I.; Tabor, S.; Kwasniewski, D.; Sorokin, D.; Yermakov, S. Forecasting Quantitative Risk Indicators of Investors in Projects of Biohydrogen Production from Agricultural Raw Materials. Processes 2021, 9, 258. https://doi.org/10.3390/pr9020258

[22] Mohammad, T.A.; Aqsha, A.; Mariam, A.; Ain, S.; Hellgardt, K.; Sumaiya, Z.A.; Farooq, S. Catalytic reforming of oxygenated hydrocarbons for the hydrogen production: Anoutlook.Biomass Conv. Bioref. 2020, 127, 109852, doi:10.1007/s13399-02001081-6.

[23] Yermakov, S.; Hutsol, T.; Mudryk,K.; Dziedzic, K.; Mykhailova, L. The analysis of stochastic processes in unloading the energy willow cuttings from the hopper. Environment, Technology, Resources. In Proceedings of the 12th International Scientific and Practical Conference, Rezekne, Latvia, 2019; pp.249-252, doi:10.17770/etr2019vol3.4159

[24] Dziedzic, K.; Mudryk, K.; Hutsol, T.; Dziedzic, B. Impact of Grinding Coconut Shell and Agglomeration Pressure on Quality Parameters of Briquette; Engineering for Rural Development: Jelgava, Latvia, 2018; pp.1884-1889, doi:10.22616/ERDev2018.17.N461. 